\title{
THE STRATEGY DEVELOPMENT AND COMPETITIVE ADVANTAGES OF MICRO SMALL MEDIUM ENTREPRISE BUSINESS INSTITUTION TOWARD REGIONAL DEVELOPMENT
}

\author{
Andi Munandar \\ Doctoral Student of Business Administration Faculty of Social \\ and Political Science University of Padjadjaran \\ Email: andimunandar999@ymail.com
}

\begin{abstract}
The implementation of "business not as usual" on the MP3EI 2011 - 2015 was held to optimize the potential of regional commodities that can increase the regional values. This research was conducted to search for the potential of UMKM in developing the potential commodities of Lampung province. The problems related to the commodities development consists of setting up the potential commodities which as based on the production copacity, so that it is difficult for those local governments to stimulate the coomdities development.

The research method was qualitative method and data collected through literature reviews and analysis of competitive advantage. The results of the research were 1) there are high potential of UMKM development, 2)UMKM should be developed in accordance with the local culture and regional commodities, 3) UMKM plays an important role in solving the social problems such as creating employment, 4) the development of human resources, technology, capital, marketing, information and management plays an important role in the development micro business, 5) the natural resources, human resources, and the world market in the global era would be a high potential if it is designed and the initiation strategy consists of the government network, NGO, private institution, individual and groups, which is managed effectively.
\end{abstract}

Keywords : strategy, business institutions, competitivve advantages

\section{STRATEGI PENGEMBANGAN DAN KEUNGGULAN BERSAING LEMBAGA BISNIS UMKM TERHADAP PEMBANGUNAN DAERAH}

\begin{abstract}
ABSTRAK
Penerapan "business not as usual" pada MP3EI 2011-2025 dilakukan dengan menggali dan mengoptimalkan potensi unggulan daerah yang dapat memberikan nilai tambah bagi daerah tersebut. Penelitian ini dilakukan untuk mengkaji potensi Usaha Mikro Kecil dan Menengah (UMKM) dalam mengembangkan komoditas unggulan di Provinsi Lampung. Permasalahan terkait dengan pengembangan komoditas unggulan yang hanya didasarkan pada kapasitas produksi, sehingga menyulitkan bagi pemerintah daerah untuk menstimulir pengembangan komoditas unggulannya.

Metode penelitian yang digunakan adalah metode kualitatif dan data yang dikumpulkan melalui studi literatur dan analisis keunggulan bersaing. Hasil penelitian adalah, Pertama; potensi pengembangan UMKM di daerah sangat besar. Kedua, pengembangan UMKM harus dilaksanakan sesuai dengan budaya lokal dan potensi yang dimiliki oleh daerah yang bersangkutan. Ketiga, sektor UMKM ini sangat berperan dalam menanggulangi masalah sosial di daerah dengan penyerapan tenaga kerja yang sangat tinggi. Keempat, peranan peningkatan SDM, pemanfaatan teknologi, akses permodalan, akses pemasaran, akses informasi, dan manajemen sangat penting dalam mengembangkan usaha mikro. Kelima; Sumber daya alam dan sumber daya manusia serta pasar dunia yang semakin terbuka pada era global merupakan potensi besar jika disain dan strategi replikasi yang meliputi kerjasama jaringan (network) pemerintah, LSM, lembaga swasta dan individu maupun kelompok dikelola secara efektif dalam bentuk kemitraan.
\end{abstract}

Kata kunci :strategi,lembaga bisnis, keunggulan bersaing, 


\section{PENDAHULUAN}

Salah satu pelaku usaha yang memiliki eksistensi penting namun kadang dianggap "terlupakan" dalam percaturan kebijakan di negeri ini adalah Lembaga Usaha Mikro, Kecil dan Menengah (UMKM). Padahal jika dikenal lebih jauh dan dalam, peran Lembaga UMKM bukanlah sekedar pendukung dalam kontribusi ekonomi nasional. Lembaga UMKM dalam perekonomian nasional memiliki peran yang penting dan strategis. Kondisi tersebut dapat dilihat dari berbagai data empiris yang mendukung bahwa eksistensi UMKM cukup dominan dalam perekonomian Indonesia (Setyobudi, 2007).

Peningkatan peran dan kegiatan usaha UMKM semakin tampak sejak krisis tahun 1997, UMKM telah menunjukkan perkembangan yang terus meningkat dan bahkan mampu menjadi penopang pertumbuhan ekonomi nasional. Hal tersebut dapat dilihat dari data BPS 2003, yang menunjukkan populasi UMKM mencapai sekitar 48,39 juta unit atau 99,85\% dari keseluruhan pelaku bisnis di Indonesia. UKM memberikan kontribusi besar dalam penyerapan tenaga kerja yaitu 99,4\% dan memberikan kontribusi terhadap Produk Domestik Bruto (PDB) sebesar Rp. $1.013,5$ triliun atau $56,73 \%$ (Lestari Hs, 2010).

Hasil penelitian oleh Bank Indonesia bekerja sama dengan LPM Unila (Bank Indonesia. 2010a), menemukan UMKM memberikan kontribusi terhadap pengurangan kemiskinan. Penelitian tersebut dilakukan pada sembilan sektor usaha baik yang tergabung dalam kelompok ILMEA (Industri Logam, Mesin, Elektronik dan Aneka) maupun IKAH (Industri Kimia, Agro Industri dan Hasil Hutan) yang ada di Provinsi Lampung. Hasil penelitian menunjukkan bahwa; 1) struktur UMKM di Provinsi Lampung masih dikuasai oleh sektor agraris terutama sektor pertanian, 2) tingkat keeratan hubungan antara penambahan satu unit usaha kecil baru dengan upaya pengurangan kemiskinan di Provinsi Lampung sangat kuat/erat, dimana setiap penambahan (pembukaan) satu unit usaha kecil baru akan berpotensi meningkatkan pendapatan riil perkapita masyarakat sebesar Rp14,57838. 3) penambahan tenaga kerja pada UMKM yang berstruktur ekonomi agraris yang didominasi oleh sektor pertanian tidak bisa digunakan sebagai media pengurangan kemiskinan karena produktivitas tenaga kerja di sektor pertanian ini sangat rendah dan 4) penambahan modal (investasi) pada UMKM tidak memiliki pengaruh yang signifikan pada upaya pengurangan kemiskinan di Provinsi Lampung. Setiap penambahan investasi pada UMKM sebesar Rp 1.000.000,- secara komulatif hanya berpotensi meningkatkan pendapatan perkapita sebesar Rp 0,826531 .

Hasil penelitian pada poin ketiga dan keempat tentunya ironi bila diandingkan dengan keunggulan Provinsi Lampung, dimana sektor Pertanian, Peternakan, Kehutanan dan perikanan memiliki kontribusi paling besar terhadap PDRB yaitu 39\%. Jumlah ini lebih besar dibandingkan industri pengolahan (14\%) dan perdagangan, restoran dan hotel (14\%) (LDA, 2010). Berdasarkan potensi tersebut tentunya perlu dikaji pengembangan model yang efektif yang dapat menciptakan UMKM komoditas unggulan yang produktif. Penambahan modal semata terbukti dari penelitian tersebut tidak meningkatkan produktifitas usaha, namun penambahan jumlah UMKM signifikan dapat mengurangi tingkat kemiskinan (poin 2). Hal ini sesuai dengan penelitian sebelumnya (Deputi Bidang Pengkajian Sumberdaya UKMK, 2006), bahwa pengembangan UMKM daerah ternyata memang harus memperhatikan daya saing komoditasnya. Bila hal ini tidak diperhatikan, berapapun penambahan modal investasi, tidak signifikan dapat meningkatkan produktifitas usaha.

UMKM memang tidak terlepas dengan berbagai kelemahan dan hambatan yang dihadapinya (Arsyad (1993:38), Idrus (1998:17), Bappenas (2010), Thee Kian wie dalam Ismail (2010). Sehingga perlu dikaji mendalam berbagai hal yang dapat mendukung produktiftas UMKM. Berdasarkan kondisi tersebut tentunya perlu dikembangkan Model UMKM Berbasis 
Komoditas Unggulan khususnya di Provinsi Lampung.

Pengembangan Model UMKM Berbasis Komoditas Unggulan Provinsi Lampung didasarkan kepada konsep MP3EI 2011-2025. Pengembangan MP3EI dilakukan dengan pendekatan breakthrough yang didasari oleh semangat "Not Business As Usual", melalui perubahan pola pikir bahwa keberhasilan pembangunan ekonomi tidak hanya tergantung pada pemerintah saja melainkan merupakan kolaborasi bersama antara Pemerintah Pusat, Pemerintah Daerah, BUMN, BUMD, dan Swasta. Pihak swasta memegang peran utama dan penting dalam pembangunan ekonomi terutama dalam peningkatan investasi dan penciptaan lapangan kerja. Kegiatan Utama untuk Koridor Ekonomi Sumatera difokuskan kepada tiga indikator utama yaitu; Kelapa sawit, karet dan batu bara. Ketiga indikator utama tersebut memiliki kontribusi secara nasional.

Hanya saja bila dilihat secara khusus pada Provinsi Lampung, komoditas unggulan Provinsi Lampung tidak hanya pada ketiga indikator utama tersebut. Provinsi Lampung justru terkenal dengan komoditas yang diakui dunia, diantaranya kopi robusta, jagung, nanas kaleng, udang dan lain sebagainya. Produksi beras Lampung menjadi salah satu lumbung nasional, dan Lampung juga penghasil tapioka. Oleh karena itu perlu dikaji secara mendalam komoditaskomoditas unggulan Provinsi Lampung beserta keunggulan bersaingnya serta pengembangan Model UMKM yang dapat mengolah komoditaskomoditas unggulan tersebut secara baik. Sehingga pemanfaatan nilai tambah produk benar-benar dapat dirasakan oleh pelaku UMKM khususnya serta peningkatan PDRB Provinsi Lampung secara luasnya.

Model UMKM Berbasis Komoditas Unggulan Provinsi Lampung diawali pada tahun pertama dengan mengkaji berbagai komoditas unggulan dan keunggulan bersaingnya serta produk-produk derivatif yang telah dikembangkan. Hal ini penting disebabkan semangat MP3EI adalah pengembangan komoditas dilakukan di dalam negeri dan bukan di negara-negara investor. Sehingga keuntungan dari nilai tambah produk benar-benar dapat dirasakan di dalam negeri bukan di negara-negara investor sebagaimana yang telah terjadi selama ini. Misalnya Indonesia saat ini belum mampu mempertahankan keunggulan bersaing kelapa sawit dan karetnya. Hal ini terlihat dengan semakin menurunnya permintaan ekspor sawit dan karet, sedangkan produksi dan differensiasi produk negara pesaing seperti Malaysia dan Thailand semakin meningkat (Purwantoro (2008) dan Departemen Pertanian (2007).

\section{TINJAUAN PUSTAKA}

Konsep Usaha Kecil itu sendiri sesungguhnya, dari 48,9 juta usaha kecil di Indonesia, hanya 1 juta unit lebih yang benarbenar dapat di sebut sebagai pengusaha kecil. Koperasi pun hanya 80 ribu lebih, lebih dari 47,50 juta pengusaha sesungguhnya dikategorikan sebagai usaha mikro. Dengan demikian, bila kita berbicara tentang UMKM perlu di ingat bahwa sebetulnya kebanyakan usaha yang kita bahas itu bersifat sangat kecil. Sampai saat ini masih terdapat perbedaan mengenai kriteria pengusaha kecil baik yang ada dikalangan perbankan, lembaga terkait, biro statistik (BPS), maupun menurut kamar dagang dan industri Indonesia (KADIN). Perbedaan kriteria tersebut adalah Bank Indonesia. Suatu perusahaan atau perorangan yang mempunyai total assets maksimal Rp. 600 juta tidak termasuk rumah dan tanah yang ditempati. Untuk Departemen Perindustrian kriteria usaha kecil sama dengan Bank Indonesia. Biro Pusat Statistik (BPS); Usaha rumah tangga mempunyai : 1-5 tenaga kerja, Usaha kecil mempunyai : 6-19 tenaga kerja, Usaha menengah mempunyai : 2099 tenaga kerja. Kamar Dagang Industri Indonesia (KADIN); Industri yang mempunyai total asset maksimal Rp.600 juta termasuk rumah dan tanah yang ditempati dengan jumlah tenaga kerja dibawah 250 orang. Departemen Keuangan; Suatu badan usaha atau perorangan yang mempunyai assets setinggi-tingginya Rp. 300 
juta atau yang mempunyai omset penjualannya maksimal Rp. 300 juta per tahun.

Sebagai permbandingan dikemukakan pula beberapa kriteria usaha kecil beberapa negara berkembang seperti India, Thailand dan Philipina. India, Industri yang memiliki pabrik dan mesin-mesin beserta perlengkapannya dengan fixed assets maksimal Rupe 2.500.000 atau sekitar Rp. 496,4 juta. Thailand Industri yang memiliki fixed assets maksimal Bath 2.000.000 atau sekitar Rp. 438,1 juta. Philipina Usaha rumah tangga industri adalah yang nilai fixed aset kurang dari Peso 100.000 atau sekitar Rp. 16 juta. Small industry adalah yang nilai fixed asetnya antara Peso $100.000 \mathrm{~s} / \mathrm{d} 1.000 .000$ atau sekitar Rp. 160,8 juta.

Usaha berskala mikro, kecil dan menengah dalam arti yang sempit seringkali dipahami sebagai suatu kegiatan usaha yang memiliki jumlah tenaga kerja dan atau asset yang relatif kecil. Bila hanya komponen ini dijadikan sebagai patokan dalam menentukan besar kecilnya skala usaha maka banyak bias yang terjadi, sebagai contoh sebuah perusahaan yang memperkejakan 50 orang karyawan di Amerika Serikat dikategorikan sebagai perusahaa kecil (relatif terhadap ukuran ekonomi Amerika Serikat). Sementara itu untuk ukuran yang sama, sebuah perusahaan di Bolivia tidak lagi masuk dalam kategori usaha kecil. Dengan demikian, diperlukan komponen atau karakteristik lain dalam melakukan penilaian ukuran usaha, misalnya dengan melihat tingkat informalitas usaha dengan berdasarkan kepada dokumendokumen usaha yang dimiliki, tingkat kerumitan teknologi yang digunakan, padat karya dan lain sebagainya.

Perbedaan beberapa kriteria tersebut dapat dimengerti karena alasan kepentingan pembinaan yang spesifik dari masing-masing sektor/kegiatan yang bersangkutan. Namun disadari pula bahwa dalam beberapa hal perbedaan tersebut dapat menimbulkan kesulitan bagi suatu lembaga peneliti terutama dalam pengambilan sampel penelitian, sehingga hasilnya dapat menimbulkan persepsi berbeda.
Sehubungan dengan kesulitan yang ditimbulkan di atas, maka sejak tahun 1995 telah diadakan kesepakatan bersama antar instansi BUMN dan perbankan untuk menciptakan suatu kriteria usaha kecil, yaitu suatu badan atau perorangan yang mempunyai total assets maksimal Rp. 600 juta tidak termasuk rumah dan tanah yang ditempati.

\section{METODE PENELITIAN}

Metode penelitian yang digunakan dalam penelitian ini berupa metode penelitian kualitatif. Penelitian dilakukan dengan pendekatan pustaka/literatur dan penelitian lapangan. Pada pendekatan pustaka dikaji literatur-literatur termasuk situs penelitian terkait komoditas unggulan dan UMKM di Provinsi Lampung, penelitian lapangan dilakukan dengan cara pengumpulan data melalui observasi dan dianalisis mengunakan teknik analisis SWOT. Berdasarkan penelitian terdahulu ditemukan bahwa pada umumnya kabupaten/kota menetapkan komoditas unggulannya, namun tidak didasarkan kepada keunggulan bersaing komoditas tersebut, sehingga menyebabkan pemerintah kesulitan menstimulir pengembangan komoditas unggulannya Deputi Bidang Pengkajian Sumberdaya UKMK (2006a). Penelitian mengenai strategi pengembangan UMKM di Jawa Tengah menunjukkan pada sektor industri pengolahan, pertanian kehutanan, perikanan serta peternakan, perlu dilakukan pemetaan produk secara lebih spesifik dan homogen (Widiyanto dan Sumarno, 2010). Penelitian oleh Bank Indonesia bekerja sama dengan LPM Unila (Bank Indonesia. 2010a), menemukan bahwa struktur UMKM di Provinsi Lampung masih dikuasai oleh sektor agraris terutama sektor pertanian, penambahan modal (investasi) pada UMKM tidak memiliki pengaruh yang signifikan pada upaya pengurangan kemiskinan di Provinsi Lampung. Hasil penelitian oleh Hayati dan Sari (2007) menunjukkan ketrampilan kepemimpinan pemilik usaha kecil; industri pengolahan, meubel dan percetakan di Bandar Lampung berpengaruh 
terhadap kinerja, kepuasan dan komitmen karyawannya.

\section{HASIL DAN PEMBAHASAN}

\section{Strategi Pengembangan}

Dalam Era persaingan bebas ini yaitu telah diberlakukannya Masayarakat Ekonomi Asean (MEA) sekarang, setiap masyarakat di Indonesia menghadapi tantangan yang berbeda dari lingkungan eksternal. Dalam kaitan ini, pemecahan masalah tidak dapat dilakukan dengan kebijakan sama yang berlaku umum dari tingkat pusat. Kebijakan dan strategi yang dikembangkan haruslah sesuai dengan spesifikasi atau kondisi yang dibutuhkan oleh daerah yang bersangkutan. Untuk itu, perlu diperhatikan bahwa peran UMKM strategis untuk menciptakan tenaga kerja, kesejahteraan dan peningkatan standar hidup masyarakat setempat. Pertumbuhan UMKM tergantung dari kondisi lingkungan bisnis yang dibuat sebagai usaha bersama antara UMKM, Pemerintah dan entitas masyarakat setempat. Adapun unsur lingkungan bisnis kondusif yang perlu menjadi perhatian, meliputi ketersediaan modal, infrastruktur dan fasilitasnya, ketersediaan tenaga terampil, layanan pendidikan dan pelatihan, jaringan pengetahuan, ketersediaan layanan bisnis, lembaga lingkungan pendukung pembangunan daerah, dan kualitas pengelolaan sektor publik. Sebagai persyaratan agar strategi pembangunan daerah bekerja dengan baik, maka harus ada evaluasi terhadap kekuatan dan kelemahan masyarakat, identifikasi kesempatan bagi UMKM, pengurangan hambatan bisnis, dan pemberian kesempatan lintas pelaku setempat untuk berpartisipasi dalam proses.

Dalam pembangunan daerah ini, strategi dan pendekatan yang bisa dilakukan, antara lain investasi dibidang infrastruktur, penyediaan insentif bagi investasi bisnis, mendorong pengembangan investasi baru, pengembangan klaster, pengembangan kemitraan, pengembangan kesempatan kerja, penyediaan layanan pelatihan dan konsultasi, pengembangan lembaga keuangan mikro, penguatan proteksi lingkungan, pengembangan tanggung jawab sosial perusahaan, perlindungan terhadap warisan budaya, dan pendirian lembaga pembangunan daerah.

\section{Pemerintah Daerah}

Pemerintah daerah dalam era otonomi daerah seharusnya mempercepat pembangunan daerah, pemerintah daerah sebagai pengambil kebijakan pembangunan harus lelalu mengintegrasikan semua lintas pelaku, termasuk berbagai unsur dalam pemerintah daerah, bisnis, organisasi nirlaba dan penduduk lainnya. Lintas pelaku harus bekerjasama untuk membuat kerangka kerja formal dan informal atau lembaga untuk mendorong interaksi dan mengatur hubungan antar lembaga. Fleksibilitas harus menjadi kunci dari kerangka kerja dan lembaga yang harus menyalurkan perhatian dan kepentingan yang relevan dalam proses dan mobilisasi sumber daya masyarakat. Percepatan pembangunan daerah mungkin memerlukan pendirian suatu organisasi pengembangan khusus, yang bertanggungjawab dalam pengordinasian seluruh lintas pelaku dan berfungsi sebagai juru bicara rencana aksi atau platform yang ingin dituju.

Organisasi ini harus membentuk jejaring untuk pembangunan daerah untuk peningkatan efisiensi pengalokasian sumberdaya serta berbagai pengetahuan dan informasi. Operasionalisasi dan pembiayaan organisasi ini harus didukung oleh lintas pelaku daerah.

Salah satu misi utama dari pemerintah daerah adalah menggambarkan dan mengimplementasikan seluruh strategi pembangunan. Proses ini harus dimulai dengan penetapan tujuan yang jelas dan memahami kondisi daerah setempat.

Entitas harus juga mempertimbangkan keberlanjutan pada semua tahapan perencanaan dan implementasi untuk menjamin suatu lingkungan yang sehat dan suatu kualitas hidup yang baik. Strategi yang diterapkan haruslah dikembangkan dengan pembagian tenaga kerja antar pelaku sesuai dengan kekuatan dan sumberdaya mereka. Sejalan dengan tren 
desentralisasi, peran pemerintah daerah menjadi semakin penting dalam pembangunan. Otoritas pemerintah daerah harus menyediakan petunjuk dan bantuan untuk efektifitas dan efisiensi implementasi pengembangan strategi. Simplikasi dan deregulasi prosedur birokrasi harus dilakukan untuk mengurangi biaya bisnis. Pemerintah daerah harus menjembatani antara masyarakat dan otoritas pemerintah yang lebih tinggi.

\section{Promosi Inovasi}

Seorang wirausaha secara umum mampu memanfaatkan kesempatan untuk pengembangan kapasitas ekonomi dan pengalokasian sumber daya secara efektif. Sejalan dengan tren baru dalam pembangunan ekonomi, wirausaha juga harus mampu menghadapi kompetisi dan berinovasi, menghasilkan pertumbuhan ekonomi, pembaharuan teknologi, penciptaan lapangan kerja dan perbaikan kesejahteraan masyarakat setempat. Sumber daya lokal harus dimanfaatkan untuk mendorong pengembangan bisnis dengan memfasilitasi pengusaha untuk mengakses informasi, ilmu pengetahuan, teknologi, modal, dan sumber daya manusia yang dibutuhkan bagi keberhasilan bisnisnya. Lebih penting lagi, otoritas daerah harus mampu melakukan upaya penyederhanaan proses administrasi bagi usaha pemula (new business start-up).

Sistem inovasi lokal merupakan mekanisme fundamental untuk penguatan kapasitas inovasi ditingkat lokal. Adapun aktor utama dalam sistem ini meliputi pemerintah setempat, industri, lembaga riset dan perguruan tinggi. Untuk penguatan operasi sistem inovasi lokal, pemerintah daerah perlu mengembangkan kolaborasi antara industri dan perguruan tinggi dengan menyediakan insentif untuk pengembangan usaha patungan antara pengusaha daerah dan perguruan tinggi. Pengembangan inkubator akan meningkatkan diseminasi ilmu pengetahuan dalam sistem inovasi.

Pembentukan klaster akan mampu merangsang penumbuhan bisnis baru dan menarik perusahaan bisnis baru dari luar daerah, sehingga menigkatkan output industri dan menciptakan kesempatan kerja baru. Melalui interaksi dan berbagai sumber daya dalam jejaring, inovasi dan perbaikan teknologi dapat ditingkatkan. Dalam kaitan ini pemerintah daerah perlu menumbuhkan iklim usaha yang kondusif sesuai dengan kondisi lokal untuk pengembangan industri klaster.

\section{Pengembangan SDM.}

Kebijakan tenaga kerja terkait erat dengan strategi pengembangan ekonomi dan kebijakan stabilitas sosial. Dan keberhasilan pada satu sisi suatu kebijakan tergantung pada keberhasilan yang lain. Unsur-unsur interaksi mempengaruhi keberhasilan kebijakan tenaga kerja meliputi seberapa baik kebijakan itu sejalan dengan seluruh strategi pengembangan ekonomi, yang juga harus membangun jejaring dengan layanan organisasi ekonomi dan sosial lain, dan bagaimana kondisi sosial dan ekonomi mempengaruhi fleksibilitas implementasinya.

UMKM dan bisnis pemula menjadi penghela penciptaan tenaga kerja di tingkat lokal. Penumbuhan UMKM dan bisnis pemula mempunyai andil pending dalam penyusunan kebijakan tenaga kerja diberbagai wilayah. Agar kebijakan UMKM dan bisnis pemula berjalan dengan baik, otoritas pemerintah daerah harus melibatkan mereka dalam setiap proses penyusunan dan implementasi kebijakan.

Pendirian organisasi pelatihan lokal perlu koordinasi antar pembisnis, tega ahli, dan perguruan tinggi. Masukan dari pebisnis dapat membantu menjamin kandungan pelatihan dapat merefleksikan keterampilan yang sesuai dengan alam kebutuhan pasar tenaga kerja. Otoritas daerah dapat menawarkan insentif untuk mengembangkan pelatihan keterampilan, dan mendorong partisipasi dalam pelatihan. Dalam era globalisasi, keterampilan yang dibutuhkan pasar berubah cepat. Tenaga kerja harus fleksibel mampu beradaptasi dengan perubahan. Oleh karena itu sangat penting untuk mempercepat kapasitas pekerja untuk mempelajari keterampilan baru, dan alih keterampilan bagi industri yang lain. 


\section{Dukungan Finansial}

Pengembangan Usaha Mikro Kecil dan Menengah (UMKM) biasanya diiringi dengan kebutuhan modal. UMKM yang semakin berkembang, disebabkan karena semakin besarnya pula peluang usaha yang dapat diakses.

Dalam kondisi tersebut biasanya UMKM tidak dapat mengembangkan usahanya lebih jauh lagi, karena kurangnya dukungan dana. Di sinilah pentingnya lembaga pemberi modal memainkan peranannya, sekaligus melalukan pendampingan. Sejumlah mekanisme dapat dilakukan sesuai dengan keragaman kondisi yang dihadapi UMKM berkaitan dengan akses finansial. Untuk pembiayaan usaha mikro biasanya memerlukan pengembangan lembaga keuangan mikro dan ketersediaan kredit yang dapat diakses mereka.

Lembaga keuangan mikro bisa berbentuk bank atau non bank, termasuk koperasi. Bagi usaha pemula, pengembangan jejaring lokal usaha malaikat (Business Angels) dapat mengatasi sebagian masalah mereka. Lembaga jaminan kredit termasuk di tingkat lokal juga memadai untuk pasar lokal yang lebih kecil. Tujuan pengembangan lembaga jaminan kredit untuk menjamin keamanan pembiayaan UMKM, membantu UMKM mengatasi keterbatasan agunan, meningkatkan minat lembaga keuangan memberikan kredit kepada UMKM dan mendukung lembaga lain yang telah berusaha membantu UMKM, sebab selama ini perbankan tidak kondusif dalam memberikan pinjaman kredit, karena kredit yang mereka kucurkan selalu berdasarkan $5 \mathrm{C}$, yakni character, capacity, capital, condition of ecconomic, and collateral.

Akibatnya perbankan selalu menerapkan berbagai persyaratan jaminan keamanan kredit yang disalurkannya. Apalagi mereka juga sering kali tidak membedakan persyaratan kredit antara usaha mikro atau kecil dengan usaha besar. Karena itulah pemerintah mendukung peran serta lembaga keuangan lain seperti lembaga modal ventura sebagai alternatif solusi didalam pemberdayaan UMKM. Keunggulan modal ventura, modal ventura adalah pembiayaan yang berbentuk penyertaan modal, pola bagi hasil, dan obligasi konversi kepada UMKM dalam jangka waktu tertentu dengan karakteristik mempunyai tingkat resiko atau modal yang ditanamkan karena bertindak sebagai investor. Modal ventura merupakan investasi aktif, yakni jika dipandang perlu melibatkan diri dalam pengelolaan usaha UMKM investasi bersifat sementara dan mengharapkan hasil atas investasi yang ditanamkan. Dibandingkan dengan perbankan, lembaga modal ventura memiliki beberapa kelebihan didalam mendukung usaha mikro, kecil dan menengah antara lain:

Pertama, lembaga modal ventural menyediakan modal seperti halnya perbankan, tetapi dengan syarat lebih sederhana dalam aspek formal maupun agunan karena lebih mengedepankan kelayakan usaha.

Kedua, selain modal, pola ventura juga menyediakan pendampingan sesuai kebutuhan UMKM, sehingga dapat berjalan lebih efektif bagi kedua pihak. Pola pendampingan ini menjadi trdemark ventura. Pendampingan ini dapat berbentuk pembinaan atau Pelatihan, konsultasi, manajemen dan perluasan pasar bagi UMKM. Ini yang menyebabkan pola modal ventura berbeda dengan perbankan. Faktor lain yang mendukung lembaga modal ventura menjadi alternatif, adalah akses jaringan di seluruh Indonesia.

\section{Modal Awal Pendanaan}

Sejak tahun 2001, modal ventural telah menjadi mitra kementrian Koperasi dan UMKM untuk menggulirkan dana penguatan permodalan kepada usaha kecil, mengengah dan koperasi melalui program modal awal pendanaan (MAP). MAP ini merupakakan dana investasi untuk disalurkan kepada usaha kecil, menengah dan koperasi (UMKMK) melalui lembaga modal ventura untuk memulai atau mengembangkan bisnis UMKMK. Program MAP bertujuan melakukan pengembangan UMKMK terutama yang bernilai tambah tinggi, menstimulasi dan menggalang partisipasi berbagai pihak dalam pengembangan basis permodalan UMKMK, serta merangsang pengembangan permodalan jangka panjang bagi UMKMK melalui penyediaan dana 
investasi (matching fund), dengan mekanisme pengembalian pokok dana MAP oleh UMKMK dilakukan dengan diangsur atau sekaligus sesuai dengan jadwal investasi UMKMK yaitu maksimal 5 tahun.

\section{Strategi Pemasaran.}

Di banyak daerah, masalah strategi pemasaran menjadi perhatian utama, khususnya untuk produk budaya lokal. Industri budaya lokal yang tradisional mungkin masih menggunakan metode pemasaran kadaluarsa. Ini bisa membuat industri ini mengalami penurunan. Tetapi, upaya mengembangkan industri budaya lokal dengan pemasaran inovatif dan modern bisa membantu meraih kembali keuntungan pasar. Kebijakan seperti ini dapat mencegah hilangnya nilai budaya dan sejarah karena dampak globalisasi.

Produk dari industri budaya lokal merupakan ekspresi budaya dan seni, yang biasanya banyak menarik bagi pembeli asing dan memiliki potensi ekspor tinggi. Walaupun secara umum, sebagian dari industri ini adalah usaha mikro yang kesulitan pemasaran di luar negeri. Pengembangan e-commerce merupakan strategi yang dapat membantu memasarkan produknya keluar negeri dengan biaya yang murah. Sebelum itu, memperkecil kesenjangan digital perlu dilakukan dan sekaligus pembangunan infrastruktur internet. Untuk mengatasi keterbatasan ukuran dan sumber daya, pembisnis budaya lokal dapat menerapkan strategi pembangunan kerjasama, seperti kerja sama pemasaran dengan pebisnis di industri budaya lokal dan bisnis lain yang saling menguntungkan. Para pasangan bisnis ini dapat bekerja sama untuk membangun asosiasi atau jejaring untuk mempromosikan produk.

\section{Membangun Kemitraan}

Pembangunan daerah sebagian besar tergantung pada kemitraan antara pemerintah, pelaku bisnis dan lembaga non pemerintah. Kemitraan ini memfasilitasi koordinasi dan kerja sama. Pasangan lokal dari sektor swasta dapat membantu mengekspolitasi kesempatan daerah dalam mengembangkan kebijakan dan strategi yang sesuai dengan kebutuhan setempat. Kunci utama dari kemitraan ini adalah mekanisme untuk mengatur dan mengkoordinir secara benar sumber daya dan upaya-upaya yang berbeda dari para pelaku yang berbeda. Perencanaan dan implementasinya dilaksanakan sesuai dengan kemampuan dan kekuatan masing-masing. Selama dalam proses ini penting untuk diperhatikan, yakni membentuk jejaring kerjasama dan mengembangkan rasa saling percaya. Karena keterbatasan institusionalisasi, kemitraan untuk pembangunan daerah kerap kurang berjalan dengan stabil. Oleh karena itu pemerintah daerah harus memimpin di depan dalam membangun mekanisme yang lebih stabil dan formal untuk membantu memberikan kemitraan sebagai basis pelembagaan dan kemampuan merancang dan menerapkan rencana pengembangan. Konsep kemitaan untuk pembangunan daerah dekat hubungannya dengan tanggung jawab sosial perusahaan (corporate social responsibility). Sejalan dengan filosofi CSR, perusahaan ingin mendedikasikan dirinya untuk membangun kemitraan lokal, memperkuat kapasitas lokal, perlindungan lingkungan dan berkontribusi dana untuk pembangunan daerah. Kesadaran akan pentingnya CSR diantara para pebisnis menjadi prasyarat penting untuk melibatkan para pebisnis dalam kemitraan untuk pengembangan daerah. Membangun kesadaran ini merupakan bidang yang perlu menjadi perhatian pemerintah daerah. 


\section{SIMPULAN}

Berdasarkan pembahasan dapat ditarik beberapa kesimpulan. Pertama; potensi pengembangan UMKM di daerah sangat besar. Kedua, pengembangan UMKM harus dilaksanakan sesuai dengan budaya lokal dan potensi yang dimiliki oleh daerah yang bersangkutan. Ketiga, Sektor UMKM ini sangat berperan dalam menanggulangi masalah sosial di daerah dengan penyerapan tenaga kerja yang sanagat tinggi. Keempat, peranan peningkatan SDM, pemanfaatan teknologi, akses permodalan, akses pemasaran, akses informasi, dan manajemen sangat penting dalam mengembangkan usaha mikro. Kelima; Sumber daya alam dan sumber daya manusia serta pasar dunia yang semakin terbuka pada era global merupakan potensi besar jika disain dan strategi replikasi yang meliputi kerjasama jaringan (network) pemerintah, LSM, lembaga swasta dan individu maupun kelompok dikelola secara efektif dalam bentuk kemitraan.

\section{DAFTAR PUSTAKA}

Arsyad, Lincolin. 1988. Ekonomi Pembangunan. Bagian penerbit STIE YPKN Yogyakarta.

Asmara, Anjal Anie. "Pola Pemasaran Yang Efektif Untuk UKM." Makalah disampaikan pada Seminar UKM Strategi Pengembangan Usaha Kecil Menengah Dalam Rangka Menghadapi Persaingan Global, Yogyakarta, 2 Oktober 2004.

Bank Indonesia. 2010a. Peran Usaha Mikro, Kecil dan Menengah dalam Pengentasan Kemiskinan Di Provinsi Lampung. Boks 2.

www.bi.go.id/NR/rdonlyres/D15253E30DE4-4EDC.../Boks2.pdf. diakses 20 May 2010

Bank Indonesia. 2010b.

http://www.bi.go.id/sipuk/id/?id=2\&no $=\mathbf{1 0 1 0 3 0 5} \&$ idrb=21\&prop=35. diakses 20 May 2010
Bank Indonesia. "Statistik Ekonomi Keuangan Indonesia." 1995.

Bappenas. 2010. Pemberdayaan Koperasi, Dan Usaha Mikro, Kecil, Dan Menengah. Bab 20. www.bappenas.go.id/get-fileserver/node/165. Diakses 23 May 2010.

Chang, Willian. "Rakyat Kecil di Tengah Instabilitas Sosial." Masyarakat Versus Negara. Kompas, Jakarta, 2002.

Departemen Pertanian. 2007. Prospek Dan Arah Pengembangan Agribisnis Karet. Edisi Kedua. Badan Penelitian dan Pengembangan Departemen Pertanian.

Deputi Bidang Pengkajian Sumberdaya UKMK. 2006a. Pengkajian Peningkatan Daya Saing Usaha Kecil Menengah yang Berbasis Pengembangan Ekonomi Lokal. Jurnal Pengkajian Koperasi dan UKM. Nomor 2 Tahun I.

Deputi Bidang Pengkajian Sumberdaya UKMK. 2006b. Pengkajian Peningkatan Daya Saing Usaha Kecil Menengah yang Berbasis Pengembangan Ekonomi Lokal. Jurnal Pengkajian Koperasi Dan Ukm. Nomor 1 Tahun I.

Dipta, I Wayan. 2008. Strategi Penguatan Usaha Mikro, Kecil Dan Menengah (UMKM) Melalui Kerjasama Kemitraan Pola CSR. Infokop. Volume 16 - September hal: 6275.

Ernawati. "Upaya Meningkatkan Peran UMKMK." Warta Kemitraan Bagi Pengembangan Ekonomi Lokal (KPEL, Jakarta, Edisi Oktober Bappenas, UNDP, UN-HABITAT, 2002.

Endang, Sri Nuryani. "Peran Pemerintah Dalam Pengembangan UKM Menghadapi Pasar Global." Makalah disampaikan pada Seminar UKM Strategi Pengembangan Usaha Kecil Menengah Dalam Rangka Menghadapi Persaingan Global, Yogyakarta, 2 Oktober 2004.

Hayati, Keumala dan Sari, Aida. 2007. Keterampilan Kepemimpinan Pengusaha Industri Skala Kecil (Studi di Bandar Lampung). Jurnal Ekonomi dan Bisnis Indonesia. Volume 22, No: 2, April 
2007, Hal: 197-214. Terakreditasi Nasional.

Hasanullah. "Peranan PPUK Bank Indonesia Dalam Pemberian KUK oleh Perbankan Di Indonesia." Jurnal Magister Manajemen. No. 26, Jakarta, Badan Penerbit IPWI, 1997.

Ismail, Zarmawis. Pemberdayaan Usaha Kecil dan Menengah. Bab III www.pacific.net.id/pakar/sadli/1299/131 299.html. diakses 20 May 2010.

Karsidi, Ravik dan Irianto, Heru. 2005. Strategi Pemberdayaan UMKM di Wilayah Surakarta. Makalah disampaikan dalam dalam Diskusi Regional Kerjasama Bank Indonesia Solo dengan Badan Koordinasi Pembangunan Lintas Kabupaten/Kota Wilayah II Surakarta Provinsi Jawa Tengah.

Ketetapan MPR Nomor XVI Tahun 1998 Tentang Politik Ekonomi DalamRangka Demokrasi Ekonomi.

Lampung Dalam Angka. 2010.

Lembaga Penelitian SMERU. 2003. Buku I: Peta Upaya Penguatan Usaha Mikro/Kecil di Tingkat Pusat Tahun 1997-2003. Kerjasama Lembaga Penelitian SMERU dengan Kementerian Pemberdayaan Perempuan.

Lestari Hs, Sri. Perkembangan Dan Strategi Pengembangan Pembiayaan Usaha Mikro Kecil Dan Menengah (UMKM). www.smecda.com/deputi7/file_Infokop/ VOL15.../6_\%20lestari.pdf. Diakses 23 Maret 2012.

MP3EI 2011 - 2025. Masterplan Percepatan dan Perluasan Pembangunan Ekonomi Indonesia 2011-2025.

Pfeffer, Jeffrey. 1994. Competitive Advantage Through People, Unleashing Power of The Workforce. Harvard Business School.

Porter, Michael E., 1985. Competitive Advantage, Creating and Sustaining Superior Performance. New York: The Free Press.
Purwantoro, R. Nugroho. 2008. Sekilas Pandang Industri Sawit. USAHAWAN LMFEUI. edisi No. 04/2008.

Rangkuti, Freddy. "Analisa SWOT Teknik Membedah Kasus Bisnis.” Jakarta, PT. SUN, 2000.

Setyobudi, Andang. 2007. Peran Serta Bank Indonesia Dalam Pengembangan Usaha Mikro, Kecil dan Menengah (UMKM). Buletin Hukum Perbankan dan Kebanksentralan. Volume 5, Nomor 2, Agustus 2007.

Sriyana, Jaka. 2010. Strategi Pengembangan Usaha Kecil dan Menengah (UKM): Studi Kasus Di Kabupaten Bantul. Simposium Nasional 2010: Menuju Purworejo Dinamis dan Kreatif. Hal: 79103.

Widiyanto dan Sumarno, 2010. Strategi

Pengembangan UMKM di Jawa Tengah. Eksplanasi. Vol. 5. No. 1 edisi Maret. 